\title{
The saola Pseudoryx nghetinhensis in Vietnam - new information on distribution and habitat preferences, and conservation needs
}

\author{
Neville Kemp, Michael Dilger, Neil Burgess and Chu Van Dung
}

In 1995 a new population of the recently described, endangered bovid, the saola Pseudoryx nghetinhensis, was found in the forests of Bu Huong, Nghe An Province in Vietnam. The new records were to the north of the main known populations, and represent an important range extension for the species. The new population may number only 30 individuals and appears to be confined to river valleys in primary forest. Investigations at this site and a compilation of published and unpublished data suggest that the range of the species in Vietnam and Laos includes over $5000 \mathrm{sq} \mathrm{km}$ of mountainous terrain, four protected areas (Vu Quang and Pu Mat, Nature Reserves [Vietnam], Nakai Nam Theun and Hin Namnu National Biodiversity Conservation Areas [Laos]), and three proposed protected areas (Bu Hong [Vietnam], Nam Chuan and Nakai Nam Theun Northern Extension National Boidiversity Conservation Areas [Laos]). All known locations for the species are mountainous with steep river valleys, covered by evergreen or semideciduous forests between 300 and $1800 \mathrm{~m}$, with low human disturbance. The main threats to its survival are hunting by local villagers and clearance of forests to provide farmland. Both need to be tackled if the saola and other forest-endemic species of this area are to persist.

\section{Introduction}

A new species of bovid, the saola Pseudoryx nghetinhensis, was discovered in May 1992 in Vu Quang Nature Reserve, Ha Tinh Province, Vietnam (Dung et al., 1993, 1994). Global interest in the discovery initiated surveys in $\mathrm{Vu}$ Quang and adjacent areas in Vietnam and neighbouring Laos, to study further the distribution, behaviour and status of the species. In 1992 and 1993, surveys were carried out in Vu Quang and other forest sites in Nghe An Province, Vietnam, by a joint team from the Ministry of Forestry and World Wide Fund for Nature (WWF), resulting in over 20 specimens of partial remains of saola (Dung et al., 1993, 1994). In 1994, expeditions in Laos were carried out by the Wildlife Conservation Society of New York and the Department of
Forestry of the Lao People's Democratic Republic (WCS, 1994; Berkmüller et al., 1995; Schaller and Rabinowitz, 1995). These surveys confirmed the presence of saola in 23 locations, in areas adjacent to the Vu Quang Nature Reserve in Vietnam, but also further to the south and west.

Since 1993, Frontier-Vietnam has been surveying forested areas in northern Vietnam. From April to July 1995 surveys were completed at $\mathrm{Bu}$ Huong, Quy Chau district $\left(104^{\circ} 45^{\prime} \mathrm{E}, 19^{\circ} 30^{\prime} \mathrm{N}\right.$ and $\left.105^{\circ} 00^{\prime} \mathrm{E}, 19^{\circ} 15^{\prime} \mathrm{N}\right)$, in the centre of Nghe An Province. The Bu Huong site has been proposed as a nature reserve and covers 49,000 ha, much of which is natural forest. This paper presents survey data from Bu Huong, and a compilation of other published and unpublished information on $P$. nghetinhensis from other areas. 


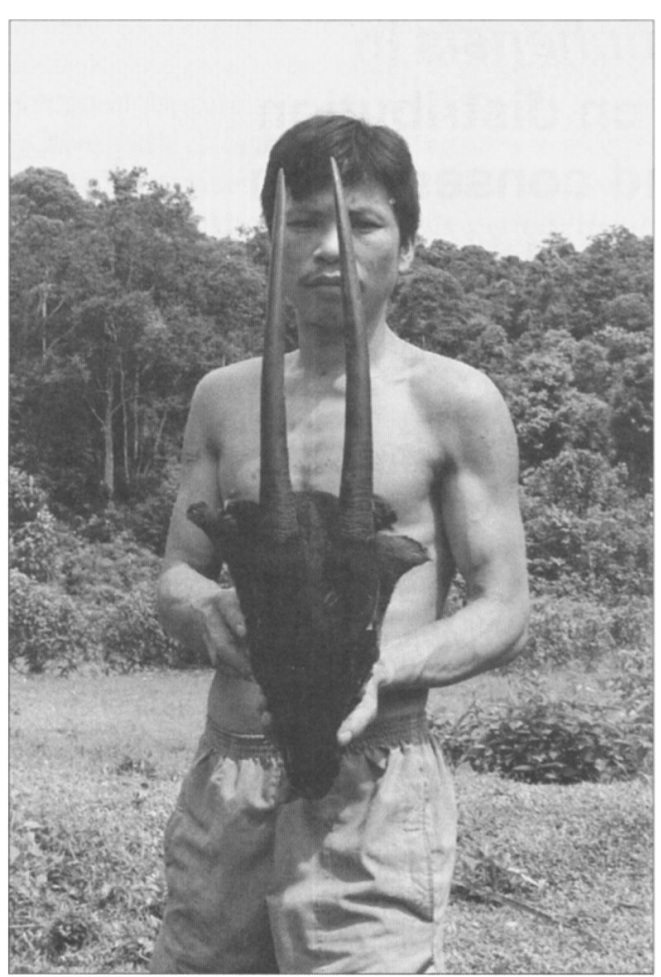

Local Thai minority hunter with skull of saola shot in Bu Huong (M. Dilger).

\section{Methods}

Hunters and other forest users from nine villages around $\mathrm{Bu}$ Huong were interviewed in Vietnamese about the abundance, distribution and behaviour of saola in the forest. As noted in Laos (Schaller and Rabinowitz, 1995), the killing or sighting of saola by local people remained prominent in their memories because of the rarity of such events. This was also the case in Bu Huong, where even local people who had not seen the animal knew of forest areas where and occasions when local hunters had encountered the species. Only first-hand information from six hunters has been regarded as reliable, and second-hand information was used as corroboration. Additional information was provided by one of the authors (C.V.D.), who has collected records and photographic evidence of saola remains throughout Nghe An Province, including eight localities around Bu Huong since 1994.
Partial remains of saola, which had been shot or captured from $\mathrm{Bu}$ Huong forest were studied, facilitated by the practice of hunters keeping trophies. Four sets of horns with skulls were examined as well as a set of hoofs from a young calf. The forest was surveyed on foot between 22 April and 20 July 1995 by teams of three to five people to assess the abundance and distribution of larger mammals. Surveys represented over 2 personmonths of survey effort, of which half was carried out with local guides or hunters with tracking dogs who knew the habitats of many forest animals, especially saola.

Published and unpublished data on the distribution, status, habitat preferences and major threats to the saola were compiled to assess the current state of knowledge of this animal (Dung et al., 1993, 1994; WCS, 1994; Berkmüller et al., 1995; Dawson, 1995; Schaller and Rabinowitz, 1995; Kemp et al., 1995, 1996; Chu Van Dung, pers. comm; Bui Tuan Viet, pers. comm; T. Evans, pers. comm; Le Mong Chan, pers. comm.).

\section{Distribution of saola in Vietnam and Laos}

In May 1995 the known range of saola in Vietnam was between $104^{\circ} 05^{\prime} \mathrm{E}, 19^{\circ} 25^{\prime} \mathrm{N}$ and $105^{\circ} 50^{\prime} \mathrm{E}, 18^{\circ} 05^{\prime} \mathrm{N}$, covering an area of $4000 \mathrm{sq}$ $\mathrm{km}$ of montane and lowland evergreen rain forest at 200-2000 m (Dung et al., 1993). It included the $\mathrm{Vu}$ Quang Nature Reserve and $\mathrm{Pu}$ Mat Nature Reserve, which cover the two largest areas of pristine forest in Vietnam. The northern edge of the range was believed to be the northern end of the Truong Son mountain range, south of the Song Ca river (Dawson, 1995). The known range of the species in Laos reflects that in Vietnam, located along the border between the two countries from $18^{\circ} 25^{\prime} \mathrm{N}$ to $17^{\circ} 05^{\prime} \mathrm{N}$ at $500-1400 \mathrm{~m}$ (Schaller and Rabinowitz, 1995). The Nakai Nam Theun National Biodiversity Conservation Area (NNT NBCA) covers part of this range.

Figure 1 shows previously known locations of remains of $P$. nghetinhensis in Vietnam and Laos, new records around the proposed 
boundaries of Bu Huong Nature Reserve, and some locations where the species may also occur because of the existence of suitable habitat (Dung et al., 1994). The new records are $25-47 \mathrm{~km}$ from the nearest locations south of the Song Ca river. According to C.V.D., remains of saola have also been found elsewhere in Nghe An Province. He believed that the original range probably extended north to the Song Hieu river $\left(19^{\circ} 30^{\prime} \mathrm{N}\right)$, which runs through Que Phong and Quy Chau, Nghe An Province. There are areas of forest remaining on the Laos border north-west of Que Phong, which may also support saola if C.V.D. is correct

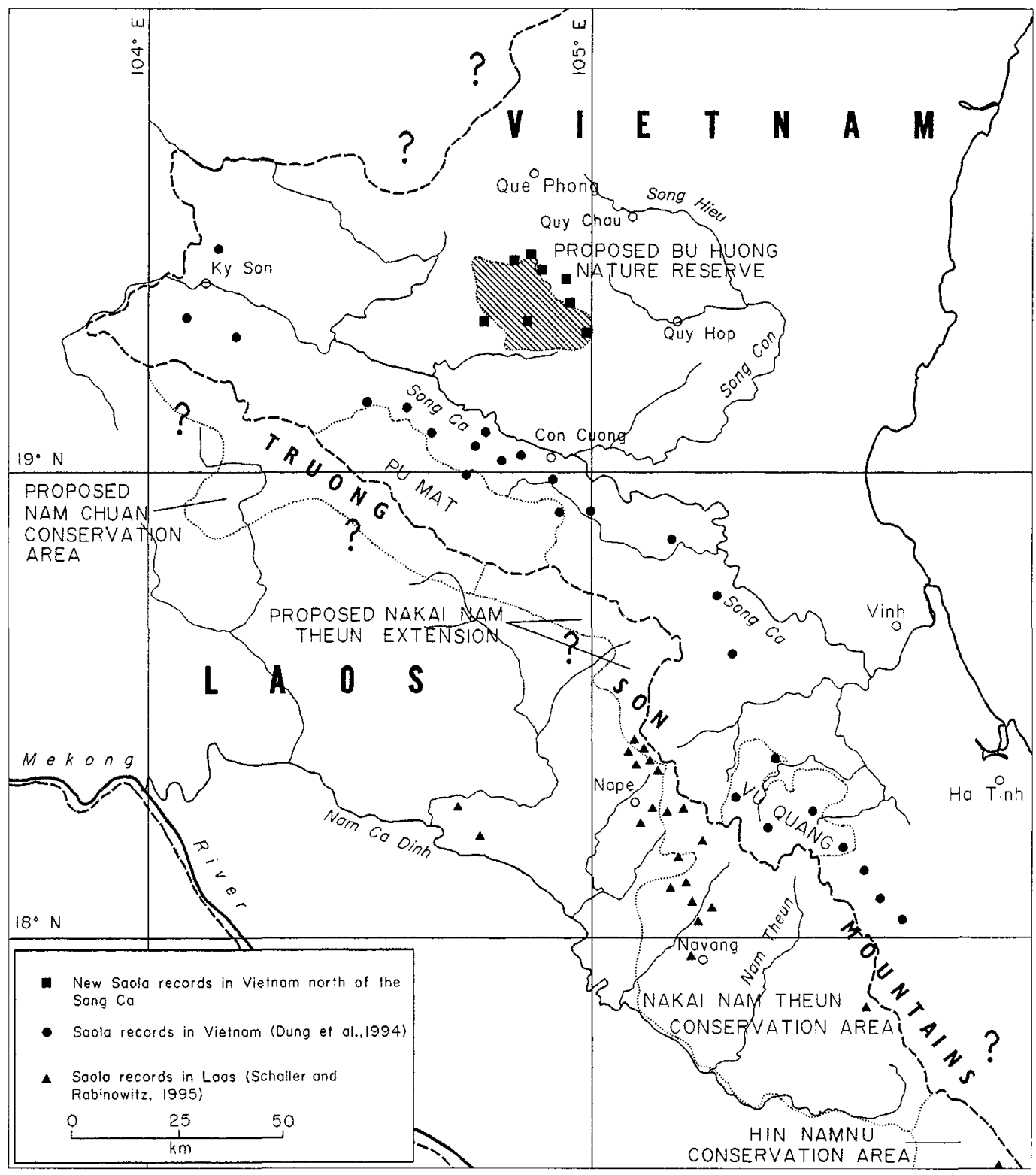

Figure 1. Map of saola records (mainly hunted specimens in villages outside the forest) in Vietnam and Laos, and other areas where there is forest and saola could occur. 
(Figure 1). However, this area has been studied by WWF staff, who found no remains of saola, or circumstantial evidence from interviews (Dawson, 1995). We believe that the discovery of any new populations of saola in Nghe An Province is unlikely.

\section{Distribution in Bu Huong}

The geographical locations of saola remains found in hunters' houses and an area, consisting of several upper river valleys, where the saola was reported to occur are shown in Figure 2. The hunters interviewed said that they sighted saola exclusively in this area. With the evidence currently available, the distribution of saola appears to be patchy on a local scale, which agrees with the situation reported in Laos (Schaller and Rabinowitz, 1995). However, it remains possible that saola exist in other areas of Bu Huong. Even though hunters knew all parts of the reserve well, they did not visit the area around Phu Lon regularly because of the difficulty of access. The key feature of the area occupied is its

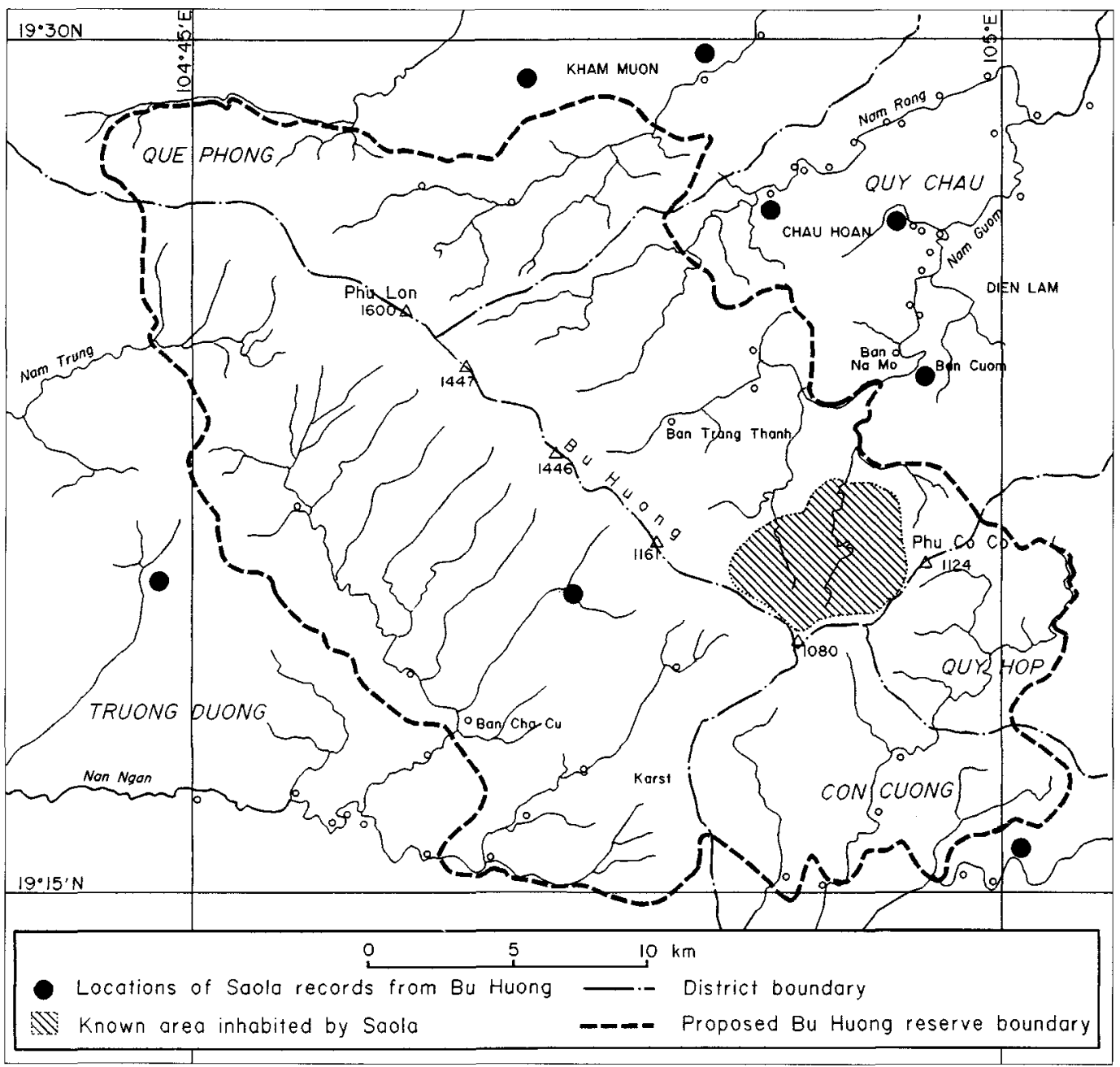

Figure 2. Map of the proposed Bu Huong nature reserve, showing the geographical location of saola records (hunted specimen remains) and an area known to be inhabited by saola. 
remoteness from human disturbance. Hunters reported that the saola was never seen close to villages or in the lower valleys, in contrast to the Indian muntjac Muntiacus muntjac, which was frequently seen and heard in secondary forest near villages.

\section{Habitat preference of saola at Bu Huong}

Bu Huong is a mountainous area dominated by a ridge running north-west to south-east through the centre of the proposed reserve. The area has many steep-sided valleys and perennial streams. The forests extend from 400 $\mathrm{m}$ to the highest peaks along the ridge at 1600 $\mathrm{m}$. The forest of the proposed reserve mainly comprises lowland evergreen rain forest and lower montane rain forest (following Whitmore, 1975). These forest types are 'wet evergreen forests' with a small deciduous element. The forest in Bu Huong has an extremely diverse flora, with an estimated 2000 species (Le Mong Chan, pers. comm.). Dense forest covers less than $200 \mathrm{sq} \mathrm{km}$. Several 0.2ha vegetation plots in the dominant forest formations of the proposed reserve have been studied in detail (Kemp et al., 1996). Lowland evergreen rain forest $(400-750 \mathrm{~m})$ is dominated by Hopea mollissima and Vatica fleuryana (Dipterocarpaceae). Other dominant species include Madhuca pasquieri (Sapotaceae), Diospyros oblongifolia (Ebenaceae), Beilschmiedia spp., Cryptocaria spp. and Cinnamomum spp. (Lauraceae), Ormosia spp. (Fabaceae), and Sterculia spp. (Sterculiaceae). The ground flora is dominated by species of Melastomataceae, Zingiberaceae and Arecaceae. Bamboo species are also a frequent component of the understorey.

The lower montane rain forest (over $750 \mathrm{~m}$ ) is dominated by species from the families Lauraceae (Cinnamomum spp, Cryptocaria spp., Lindera sp., Litsea sp. and Machilus sp.), Fagaceae (Quercus spp. and Castanopsis spp.), and Juglandaceae (Engelhardtia sp.). The coniferous species Fokienia hodginsii and Podocarpus fleurii were also found in small numbers in the montane forests. Large areas where the understorey is dominated by thick bamboo groves (Chimonobambusa sp. and Dendrocalamus sp.) were common at higher elevations. Although the area said to be inhabited by saola (Figure 2) was not studied in detail by the Frontier survey, the dominant components of the forest were floristically similar to those described above.

The forest types found in Bu Huong share many floristic similarities with the forest types at Pu Mat, even though $\mathrm{Bu}$ Huong receives a lower rainfall $(800-1000 \mathrm{~mm})$ than $\mathrm{Pu}$ Mat (1268-1791 mm; Kemp et al., 1995, 1996). Current knowledge indicates that the saola prefers wet lowland evergreen forest habitats (characterized by the Dipterocarp species Hopea mollissima in Vietnam) and evergreen montane forests. Forest types within the range of saola in Laos are believed to have similar vegetation to those in Vietnam (Schaller and Rabinowitz, 1995) and most records cluster around areas of 'wet evergreen forest' (WCS, 1994; T. Evans, pers comm.). This forest type only occurs in a few border areas in Laos and may explain the localized distribution of saola within the NNT NBCA, Hin Namnu NBCA and areas to the north (T. Evans, pers comm.). Unlike some of the reports of saola in Dung et al. (1994), the population at Bu Huong was only encountered in areas with no human disturbance, with no reports coming from the lower valley areas, which supported secondary, degraded and agricultural vegetation.

\section{Quantifying annual offtake by hunters around Bu Huong}

The first sighting of saola in Bu Huong by the hunters from Ban Cuom village was in 1986. It is not known if other villages or villagers sighted saola before this time. The total known number of saola killed in Bu Huong now numbers 27 individuals (Chu Van Dung, pers. comm.). During our survey ( 3 months) two saola were killed. One was a juvenile, which was captured alive but died next day. The remains of four saola were found in hunters' houses (two adults and two juveniles), with these and other records being concentrated around Ban Cuom, where we based 
our study. The number of animals killed by a single hunting group from Ban Cuom since 1986 is 11. The number of killings per year fluctuates considerably because killings are opportunistic, but in 1995 at least eight individuals were killed.

One experienced hunter interviewed stated that saola normally occurred in small social groups, an adult and young being the most commonly sighted grouping. He estimated the saola population in Bu Huong at about 30 individuals. However, this was not from any accurate surveys and is really only a guess. During the forest survey on foot no sightings, tracks or other traces were recorded and we must conclude that the density is low and the population small.

\section{Threats to the survival of saola}

The saola is certainly one of the most endangered species in the region. Its discovery in another location, outside the previously known range, has important implications for conservation efforts and for further survey work. In general terms, the larger the range and population size of an animal the greater its chance of survival in the future. However, the threats to the surviving populations are very great. The two most serious threats are hunting, and loss of forest habitat through logging and conversion to farmland. All records of saola are from remains of animals shot or captured by hunters. The local people of the Bu Huong area (Thai and Thanh minorities) are traditional hunters and their attitudes to hunting are deeply entrenched and difficult to change. Saola are shot for their meat, but hunters also gain high esteem within the village on the production of a carcass. Because of their scarcity local people place a higher value on saola than on more common species such as Muntiacus muntiac and wild boar Sus scrofa. Hunters were also aware of the intense interest from the world's scientific community, increasing their motivation to capture live specimens. This desire to shoot or capture saola because of their value cannot be good for the future survival of the species in Vietnam.
In the $\mathrm{Bu}$ Huong area there is widespread conversion by the local people of forest land to agricultural land. The dominant form of agriculture is the cultivation of hill rice through 'swidden' agriculture. New areas of forest must be cleared regularly for cultivation because the soil quickly loses its fertility and is eroded. The fallow periods are short and land is usually cleared again for farming after 7-15 years, preventing forest regrowth. The productivity of fallow areas is always lower than that of newly cleared land, causing a need to clear new areas of more mature forest. It was estimated that the clearance of high mature forest (primary and slightly disturbed secondary) is currently around 50 ha per year in Dien Lam commune alone. This commune covers one-eighth of the total proposed area of the reserve and, if rates of clearance are similar in other areas, clearance of forest types that are suitable habitat for saola could exceed 400 ha per year. This rate may continue to increase as the population grows (currently around 5 per cent per year) and the productivity of previously cleared areas declines. Because saola primarily inhabit pristine forest areas, the alteration of these habitats is a considerable threat to their survival and that of other forestendemic species in Bu Huong.

The threats to the saola encountered at $\mathrm{Bu}$ Huong are similar to those affecting all reserves established within the species's range (Table 1). The generally high levels of these threats are of great concern for the conservation of saola.

\section{Discussion}

If the saola is to be effectively conserved at $\mathrm{Bu}$ Huong, and more generally in Vietnam and Laos, two major aims must be achieved. Hunting of the saola and clearance of primary forest within its range must be stopped or considerably reduced. The actions necessary to achieve these aims are more difficult to state. $\mathrm{Bu}$ Huong is due to become a nature reserve and this may afford the area some protection. Commercial logging has already been stopped and an official ban on forest clearance and 
Table 1. Levels of threat (hunting and loss of habitat) to populations of saola inside nature reserves and proposed nature reserves in Vietnam and Laos

\begin{tabular}{lll}
\hline Protected area & Hunting threat & Habitat loss \\
\hline Bu Huong (1) & Very high & High \\
Pu Mat (2) & Very high & Medium \\
Vu Quang (3) & Very high & High \\
NNT NBCA (4) & Very high & High \\
\hline
\end{tabular}

(1) Kemp et al, 1996. (2) Kemp et al., 1995.

(3) Dawson, 1995. (4) WCS, 1994.

Threats were assessed from the above reports on an intuitive scale, with respect to each individual reserve.

hunting within the boundaries of the reserve will be enacted. However, as with much of the region where saola occurs, if conservation and protected area management are to be successful, the needs of the local population must be taken into account.

Local people's attitudes towards the saola and its conservation remain a major obstacle for conservation programmes. Amongst the communities, there was some awareness that forest resources were declining, but the general perception was that resources were still plentiful. Moreover, the hunters showed little or no understanding of the principles of resource management of the species that they hunted. Everything that was encountered during hunting trips was shot or captured, if possible. Although the saola was valued by hunters, there seemed to be little concern about its decline or local extinction. Education programmes stressing the value of keeping a viable wild population of saola and other forest species for future generations, and the provision of suitable alternatives to hunting, such as animal husbandry, may help to reduce the levels of hunting. The saola is also a protected species in Vietnam and hence, as was advocated by Dung et al. (1994), strict penalties for killing saola could also be introduced and enforced. Because there are only a few people who hunt on a regular basis the enforcement of regulations would cause a dramatic reduction of hunting pressure. Alternative agricul- ture systems are also needed to reduce deforestation, and to sustain the large and increasing human population. Examples of effective systems could be seen in the area; these used the same plots of land with rotation cropping and Cinnamomum sp. plantations. The dependence on rice and the many traditions of growing this crop are large obstacles to overcome before agricultural improvement can be carried out.

When Bu Huong is established as a nature reserve, the majority of primary forest within the saola's known range will be protected in Vietnam and Laos (Dung et al., 1994; Schaller and Rabinowitz, 1995). The majority of the suspected range within Laos will be protected only within the Nakai Nam Theun Northern Extension and Nam Chuan protected areas (Berkmüller $e$ al., 1995). Unfortunately, poorly policed legislation will have little effect on the conservation of the saola and its habitat. In many reserves and national parks in Vietnam little is done to enforce conservation regulations or to initiate alternative strategies for the conservation of wildlife owing to many inadequacies and lack of resources. These problems are beyond the scope of this paper, but their solution will require considerable capacity building within the relevant Vietnamese authorities.

$\mathrm{Bu}$ Huong is surrounded by severely degraded forest, agricultural land and scrub, which are unsuitable habitats for saola. Therefore, the population of saola at $\mathrm{Bu}$ Huong effectively lives in a 'forest island refuge' with no immigration or mixing with other populations. This population is reliant for its future survival on the continued existence of its habitat and probably also on a major reduction in the levels of hunting.

\section{Acknowledgements}

Information from Bu Huong was collected by members of Frontier-Vietnam Expedition VN9502, under the auspices of the Society for Environmental Exploration, London and the Xuan Mai Forestry College, Ministry of Forestry, Hanoi. Particular thanks are due to Tom Evans for reading the draft document and providing information from Laos; Kot Rafi, BP Vietnam, and Vietnam Investment 
Review who provided financial assistance, without which some of the survey work could not have been carried out; Bui Tuan Viet and Le Mong Chan for translating interviews with hunters and other local people; Racal Survey Australia Ltd.; and the comments of two anonymous referees.

\section{References}

Berkmüller, K., Evans, T., Timmins, R. and Vongphet, V. 1995. Recent advances in nature conservation in the Lao PDR. Oryx, 29, 253-260.

Dawson, S. 1995. Saola (Pseudoryx nghetinhensis) Studies in Nghe An and Ha Tinh Provinces, Vietnam. Consultancy report, World Wide Fund for Nature - Indochina Programme, National Wildlife Federation and World Conservation Union.

Dung, V.V., Giao, P.M., Chinh, N.N., Tuoc, D. Arctander, P. and McKinnon J. 1993. A new species of living bovid from Vietnam. Nature, 363, 443-445.

Dung, V.V., Giao, P.M., Chinh, N.N., Tuoc, D. and McKinnon, J. 1994. Discovery and conservation of the Vu Quang Ox in Vietnam. Ory $x, 28,16-21$.

Kemp, N., Chan, Le Mong and Dilger, M. 1995. Site Description and Conservation Evaluation: $P u$ Mat Nature Reserve, Nghe An Province, Vietnam. Frontier Vietnam Scientific Report No. 5, Society for Environmental Exploration, London.

Kemp, N., Chan, Le Mong and Dilger, M. 1996. Site Description and Conservation Evaluation: Proposed Bu Huong Nature Reserve, Nghe An Province,
Vietnam. Frontier Vietnam Scientific Report No. 7, Society for Environmental Exploration, London.

Schaller, G.B. and Rabinowitz, A. 1995. The saola or spindlehorn bovid Pseudoryx nghetinhensis in Laos. Oryx, 29, 107-114.

WCS 1994. A Wildlife and Habitat Survey of Nam Theun National Biodiversity Conservation Area, Khammouane and Bolikhamsai Provinces, Lao PDR. A report to Protected Areas and Wildlife Division of the National Office for Nature Conservation and Watershed Management, Vientiane, Laos. The Wildlife Conservation Society, New York.

Whitmore, T. 1975. Tropical Rain Forests of the Far East. Clarendon Press, Oxford.

Neville Kemp, Westfield, Bishopswood, Chard, Somerset TA20 3SA, UK.

Mike Dilger, 21 Newport Road, Stafford ST16 1BH, UK.

Neil Burgess, Danish Centre for Tropical Biodiversity, Zoological Museum, Universitetsparken 15, DK-2100, Copenhagen $\varnothing$, Denmark, and Society for Environmental Exploration, 77 Leonard Street, London EC2A 4QS, UK.

Chu Van Dung, Department of Forest Protection, Department of Forestry, Vinh, Nghe An Province, Vietnam. 